\title{
A TERRA COMO ATIVO FINANCEIRO: MECANISMOS, PRÁTICAS E INSTRUMENTOS
}

\author{
LAND AS A FINANCIAL ASSET: MECHANISMS, PRACTICES, AND INSTRUMENTS
}

Bruna Bicalho ${ }^{\mathrm{A}}$

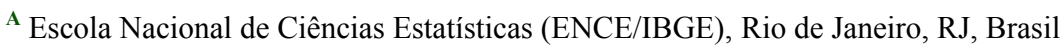

Recebido em: 05/12/2021 | 04/01/2022 DOI: 10.12957/tamoios.2022.63925

Correspondência para: Bruna Bicalho (brunabicalho@gmail.com)

\begin{abstract}
Resumo
As crises financeira, energética, ambiental e alimentar na primeira década dos anos 2000 potencializaram uma corrida mundial por terras, popularizando o conceito de land grabbing. O Brasil tem atraído o capital financeiro (inter)nacional para o campo por conta do grande "estoque" de terras e o seu preço relativamente barato nas áreas de expansão da fronteira agrícola moderna. Ressalta-se que a terra aparece, no período atual, como uma das principais formas do capital excedente se valorizar. A acumulação futura se dá a partir da absorção de partes cada vez maiores do mais-valor pela captura da renda da terra, minimizando ou anulando a tendência à queda da taxa de lucro, ou seja, os efeitos decorrentes da crise financeira. Há uma série de mecanismos, práticas e instrumentos que mostram a integração entre o capital financeiro e o controle de terras, ou seja, a financeirização da agricultura. Neste trabalho, discute-se a transformação da terra em ativo financeiro a partir das seguintes perspectivas: a abertura de empresas do agronegócio na Bolsa de Valores, a expansão dos instrumentos do mercado de capitais para financiamento da agricultura e pecuária, a criação dos fundos imobiliários agrícolas, o crowdfunding de fazendas e o surgimento das imobiliárias agrícolas.
\end{abstract}

Palavras-chave: financeirização; land grabbing; renda da terra; ativo financeiro.

\begin{abstract}
The financial, energy, environmental, and food crises in the first decade of the 2000s fueled a world race for land, popularizing the concept of land grabbing. Brazil has attracted the (inter)national financial capital to the countryside due to the large "stock" of land and its relatively low price in the expansion areas of the modern agricultural frontier. It is noteworthy that the land appears, in the current period, as one of the primary forms of surplus capital to appreciate. Future accumulation takes place from the absorption of increasingly more extensive parts of surplus-value by capturing the ground rent, minimizing or nullifying the tendency for the rate of profit to fall, that is, the effects resulting from the financial crisis. Several mechanisms, practices, and instruments show the integration between financial capital and land control, that is, the financialization of agriculture. In this paper, we discuss the transformation of land into a financial asset from the following perspectives: the opening of agribusiness companies on the Stock Exchange, the expansion of capital market instruments for financing agriculture and livestock, the creation of farmland REITs - real estate investment trust, the crowdfunding of farms, and the rise of agricultural real estate.
\end{abstract}

Keywords: financialization; land grabbing; ground rent; financial asset. 


\section{INTRODUÇÃO}

A primeira década do século XXI foi marcada por uma convergência de crises: financeira, alimentar, energética e ambiental (BERNARDES et al., 2017; BORRAS JR et al. 2012). Como resposta a essas múltiplas crises, observou-se uma corrida mundial por terras, fenômeno que ficou conhecido na literatura como land grabbing. O controle ou a apropriação das terras - tradução adotada para o termo land grabbing neste trabalho - vai além da compra do imóvel rural, podendo ser realizada através de: arrendamentos, parcerias, criação de joint ventures, compra de empresas agrícolas proprietárias de terras, negociação de ações free float na Bolsa de Valores, cessão de direito de superfície, compra de debêntures conversíveis em ações, contrato de gaveta, entre outras.

Paralelamente ao fenômeno de land grabbing, existe um processo de financeirização da economia global, o que significa " uma importância crescente das motivações financeiras, dos mercados financeiros, dos atores e instituições financeiras no funcionamento das economias doméstica e internacional" (EPSTEIN, 2005, p. 3, tradução nossa). A "financialização de tudo" (HARVEY, 2008, p. 41, tradução nossa) começou a ganhar maior visibilidade a partir dos anos 1980 com a neoliberalização, "projeto político de restabelecimento das condições da acumulação do capital e da restauração do poder das elites econômicas" (ibid., p. 27, grifo do autor) que resultou na desregulamentação e na liberalização dos mercados financeiros mundialmente.

Este trabalho tem como objetivo mostrar os diferentes mecanismos, práticas e/ou instrumentos da financeirização do campo. Para tanto, a primeira parte do texto trata da "corrida" mundial por terras e a relação com as diferentes crises. Em seguida, discute-se sobre o ciclo de reprodução do capital e a renda da terra. Estes conceitos são fundamentais para compreender as distintas formas de integração entre o capital financeiro e o controle de terras. A última parte materializa estes conceitos a partir de exemplos concretos da transformação da terra em ativo financeiro.

\section{CRISES E "CORRIDA" MUNDIAL POR TERRAS}

De acordo com McMichael (2014, p. 34) o land grabbing (ou como ele define global land grab) não é um fenômeno novo, visto as apropriações de terra desde o período colonial. Cotula (2012) também partilha da mesma visão e cita, por exemplo, os investimentos agrícolas (que envolviam largas aquisições de terras) de empresas estadunidenses, europeias e japonesas, durante os séculos XIX e XX, em países em desenvolvimento. Ou seja, o "land grabbing vem ocorrendo há séculos" (GRAIN, 2008, p. 2, tradução nossa, grifo nosso). Todavia, a contemporânea anexação de terras para a produção agrícola e/ou especulação imobiliária, acontece num período particular da história marcado por uma convergência de crises, a saber: alimentar, energética, climática e financeira (BORRAS JR et al., 2012; 
McMICHAEL, 2014; CASTILHO, BASSI, VENDRAME, 2017; FREDERICO, GRAS, 2017; FIAN, REDE, CPT, 2018).

Este cenário de crises tem grandes implicações, como o advento de novos agentes investidores financeiros, tais como os fundos de pensão, mútuos, soberanos, empresas de private equity e hedge funds, instituições bancárias etc. que, em geral, eram avessos à imobilização do capital - atuando na agricultura. Deste modo, uma forma talvez mais apropriada de descrever o que está acontecendo atualmente seria uma "renovada corrida mundial por terras" (EDELMAN, OYA, BORRAS JR., 2013, p. 1520, tradução nossa, grifo nosso).

Não existe um consenso na literatura para conceituar e caracterizar o land grabbing (EDELMAN, OYA, BORRAS JR., 2013; RODRIGUES et al., 2019) - ou seja, "a própria noção de land grabbing está em disputa” (SAUER, BORRAS JR., 2016, p. 11, grifo do autor) - e, especificamente, no caso brasileiro, tem-se ainda um problema na tradução do termo.

Traduzido literalmente, o land grabbing significa grilagem de terras, entretanto este processo histórico de apropriação ilegal de terras públicas após a Lei de Terras de 1850 pode ou não fazer parte desta "corrida" por terras. Quando presente, como explicam Castilho, Bassi e Vendrame (2017), a expropriação de terras a partir de fraudes e falsificação de títulos de propriedades associa-se, normalmente, a uma etapa introdutória do land grabbing no intuito de disponibilizar áreas para este "novo mercado global de terras" (SASSEN, 2016, p. 99). Spadotto et al. (2017) ainda acrescentam que, muitas vezes, a grilagem que antecede estas apropriações de terra é feita por empresas que, atuando como "intermediadoras terceirizadas" ou "veículos financeiros", realizam a compra/venda de terras antes da propriedade passar, de fato, para as empresas agrícolas financeirizadas (aquelas controladas pelo capital financeiro).

Alguns pesquisadores brasileiros como Fernandes $(2011,2019)$ e também a mídia, no geral, (OLIVEIRA, 2010; CASTILHO, BASSI, VENDRAME, 2017) utilizam o vocábulo "estrangeirização das terras" como sinônimo de land grabbing, mas tampouco este conceito é apropriado, visto a complexidade do fenômeno e, consequentemente, a miríade de agentes na apropriação de terras que não se restringe exclusivamente a estrangeiros. A redução de um significado ao outro (de land grabbing a estrangeirização) acaba prejudicando a compreensão mais ampla do fenômeno (SAUER, BORRAS JR., 2016). Edelman, Oya e Borras Jr. (2013) reiteram que os atores internacionais têm recebido mais atenção na mídia, entretanto o land grabbing envolve diferentes sujeitos (inter)nacionais, entidades privadas e públicas. No caso do Brasil, Bicalho (2020) mostra que existe uma forte associação entre capitais nacionais e estrangeiros, em simbiose com o Estado, na apropriação de terras.

De maneira resumida, pode-se dizer que o land grabbing é um fenômeno global de controle de terras e demais recursos naturais (hídricos, minerais e florestais) para fins de acumulação de capital como resposta, em grande parte, a uma convergência de múltiplas crises (BORRAS JR. et al. 2012). 
A crise alimentar baseia-se na inflação do preço dos alimentos na primeira década do ano 2000, como mostra a Figura 1. Neste período, os preços das principais commodities no mercado internacional cresceram exponencialmente por conta, especialmente, de dois fatores: a demanda da China por alimentos em virtude do seu intenso crescimento econômico e, o comportamento/as estratégias do mercado financeiro, ao incluir as commodities agrícolas na sua lógica de valorização, especulação (FLEXOR, LEITE, 2017) - vide, por exemplo, os novos instrumentos e produtos financeiros - decorrentes da desregulamentação das finanças e a descompartimentalização dos mercados financeiros - como o mercado de derivativos.

Observa-se, pela Figura 1, que o pico no índice de preços das commodities considerando a classe de ativos, agricultura - ocorreu em 2011, apesar da acentuada queda em 2008, por conta da crise das hipotecas subprime. Entre 2011 e meados de 2014, os preços se mantiveram constantes e, ainda, altos. Desde então, parecia que o "boom das commodities" (FLEXOR, LEITE, 2017, p. 393, grifo nosso) havia terminado com a propensão de queda no preço destas mercadorias, a partir do último trimestre de 2014 e sua estabilização entre 2016 e 2020. Contudo, desde o início de 2021, estes preços têm apresentado um crescimento acelerado, aumentando o interesse de diversos agentes no controle de terras.

Figura 1 - Índice de preços das commodities da classe de ativos: agricultura, 2000-2021

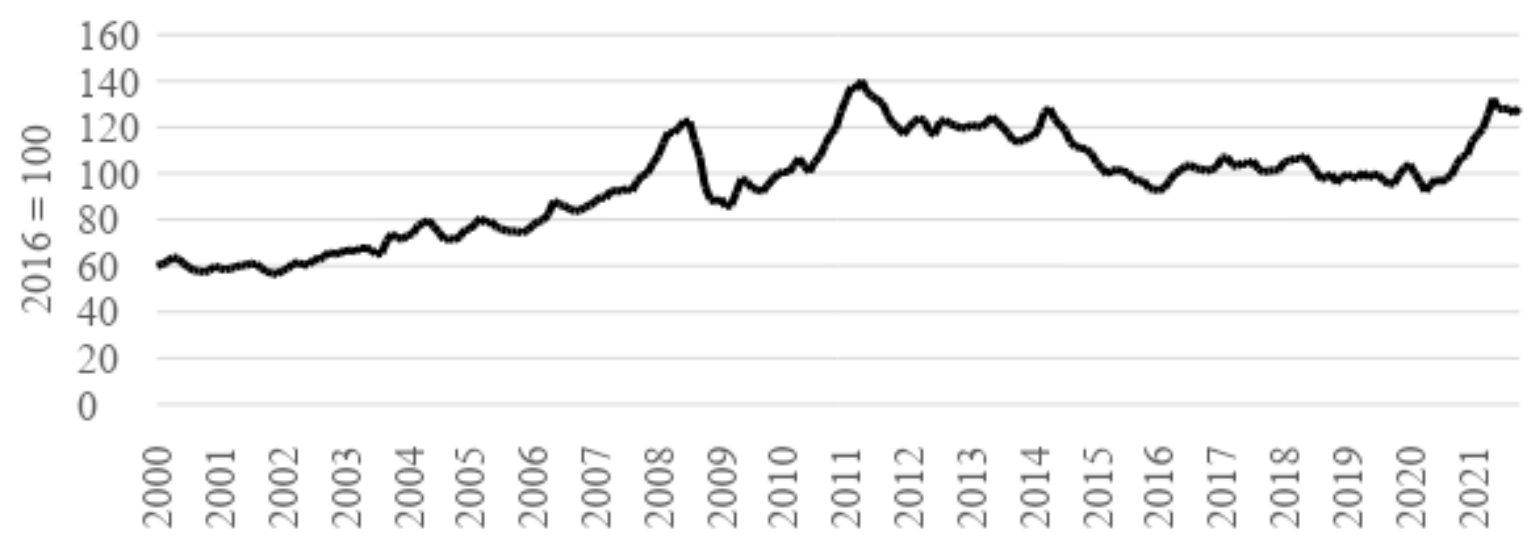

Ano

Fonte: Fundo Monetário Internacional (2021)

$\mathrm{Na}$ tentativa de compreender a lógica e a dinâmica do land grabbing, a Grain foi uma das primeiras instituições a publicar em 2008 um relatório relacionando as crises alimentar e financeira a este fenômeno. De acordo com a publicação, governos preocupados com a segurança alimentar, isto é, países que dependem de importações para alimentar a sua 
população - como Arábia Saudita, China, Coréia, Egito, Índia, Japão e Líbia - estavam adquirindo vastas extensões de terras no exterior - no Brasil, Camboja, Paquistão, Sudão e Uganda - com o intuito de produzir seus próprios alimentos. E, juntamente com as corporações e os investidores financeiros, o relatório alertava que as terras agricultáveis estavam se tornando cada vez mais privatizadas e concentradas, o que seria uma ameaça à agricultura em pequenas propriedades e aos meios de subsistência no campo (GRAIN, 2008).

Edelman, Oya e Borras Jr. (2013) também apontam que as leituras iniciais acerca do land grabbing, seja pela mídia ou por organizações não governamentais, relacionavam o fenômeno ao boom do preço das commodities em 2007-2008 (isto é, com a crise alimentar). Assim como a Grain (2008), estes autores entendem que um ponto de partida das referidas análises tratava-se justamente de governos que, temerosos em prover alimentos para a sua população - vide o aumento de preços, principalmente, de produtos como: arroz, milho, soja e trigo - estavam engajados no movimento de aquisições de terra ao redor do mundo para a produção offshore.

No contexto brasileiro, entretanto, empresas apoiadas por governos estrangeiros à procura de terras no país para a produção de alimentos é relativamente incomum, salvo casos como o do grupo Chongqing Grain Group que, com suporte do governo chinês, tentou adquirir terras agrícolas no oeste da Bahia (FAIRBAIRN, 2015) - mas, o investimento está parado devido às restrições governamentais sobre a compra de terra por estrangeiros no país (ESCHER, WILKINSON, PEREIRA, 2018; ESCHER, WILKINSON, 2019).

Já a crise energética e/ou receio de um futuro desequilíbrio nas fontes de energia diz respeito ao uso exaustivo dos recursos não renováveis - e, o progressivo esgotamento, por exemplo, das fontes de petróleo - além, da instabilidade política dos países produtores deste combustível fóssil (FERNANDES, FREDERICO, PEREIRA, 2019). Neste sentido, a redução da dependência de fontes não renováveis ou, em outros termos, a mudança na matriz energética dos países relaciona-se com o fenômeno de land grabbing, pois cresce o interesse na procura de terras agricultáveis para a produção de agrocombustíveis, como a cana-de-açúcar e o milho.

A Figura 2 mostra a expansão da área plantada de cana-de-açúcar no Brasil e o respectivo rendimento da produção (variável) entre 2000 e 2020. De acordo com Flexor e Leite (2017), este crescimento associa-se, principalmente, à produção de etanol, componente importante do Plano Nacional de Agroenergia desenvolvido pelo Ministério da Agricultura, Pecuária e Abastecimento (MAPA). Destaca-se, aqui, a importância do sujeito oculto (o Estado) fomentando a expansão desta cultura temporária, mesmo com a produtividade em queda a partir de 2009, e em áreas, como chamam a atenção os autores, anteriormente ocupadas (seja para outras produções ou para a conservação ambiental).

Figura 2 - Rendimento e área plantada de cana-de-açúcar, Brasil, 2000-2020 


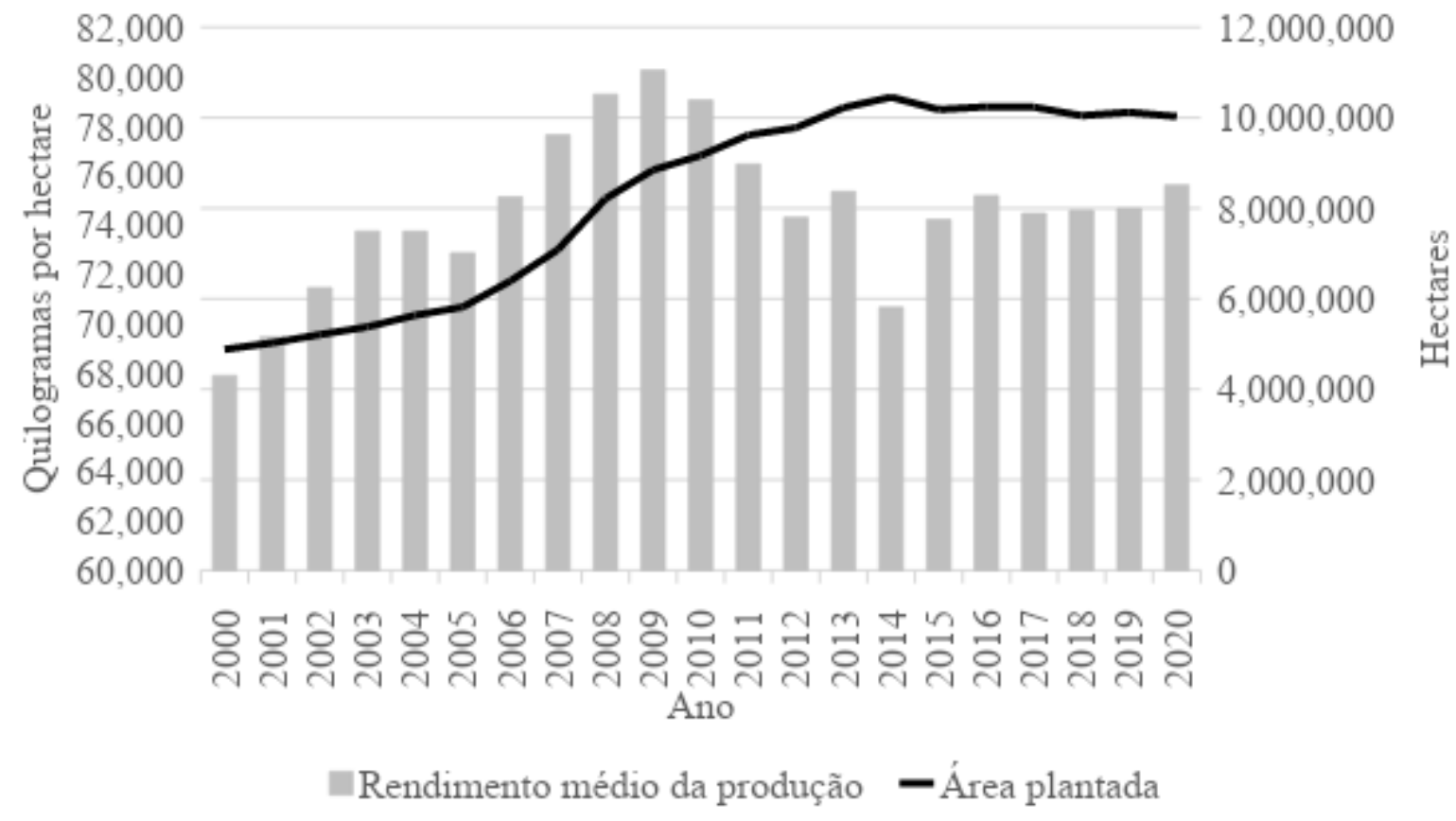

Fonte: IBGE (2020)

No caso do milho, a produção de etanol a base do grão é tendência cada vez maior no Brasil, sendo Mato Grosso o estado maior produtor. Na safra de 2019/20 a produção brasileira de etanol, a partir do milho, aumentou 107,4\% em relação à safra anterior, alcançando 1,64 bilhões de litros de etanol total (anidro e hidratado) (CONAB, 2020). Apesar de corresponder a apenas $4,6 \%$ da oferta total de etanol no país (incluindo o etanol da cana-de-açúcar), a projeção feita pela União Nacional do Etanol de Milho (UNEM) é de que o etanol proveniente do milho alcance $20 \%$ da produção nacional já em 2028 (BINI, 2020).

Em janeiro de 2020, cinco usinas de etanol de milho estavam em operação na região Centro-Sul do país, e três novas usinas iriam começar a operação ainda neste mesmo ano, duas unidades em Mato Grosso e outra em Goiás (NOVACANA, 2020). A FS Bioenergia, inaugurada em 2017, no município de Lucas do Rio Verde, em Mato Grosso, foi uma das empresas precursoras na produção de etanol de milho no país. Ela é uma joint venture entre um fundo de investimento estadunidense, o Summit Agricultural Group, e a empresa brasileira do agronegócio, Tapajós Participações S/A (FS BIONERGIA, 2020). Além do etanol, a empresa também transforma o milho em ração animal e óleo, movimentando a cadeia carne-grãos na região.

Na literatura sobre o land grabbing, os cultivos que têm múltiplos usos (servem como alimento, ração, energia/combustível e/ou matéria-prima industrial) são referidos como flex crops (culturas flexíveis) - justamente pelo fato de poderem ser intercambiados "facilmente" (no sentido de versatilidade), o que é interessante para fins de investimento, devido à diversificação do portfólio. Assim, a decisão sobre produzir açúcar e/ou etanol a partir da 
cana-de-açúcar, por exemplo, relaciona-se com o preço destes produtos no mercado (BORRAS JR. et al., 2012).

A crise climática, ou em outros termos, o aquecimento global decorrente da emissão de gases poluentes na atmosfera (sobretudo, da queima de combustíveis fósseis), por sua vez, relaciona-se com o land grabbing por conta do fomento das apropriações de terra "em nome da 'sustentabilidade', 'conservação' ou 'valores verdes"” (FAIRHEAD, LEACH, SCOONES, 2012, p. 238, tradução nossa). Este controle de terras para fins ambientais (ou green grabbing) ocorre a partir de mecanismos distintos, como o mercado de créditos de carbono. Em junho de 2020, a Adecoagro foi a primeira empresa no Brasil a comercializar créditos de carbono (CBio), instrumento financeiro negociado na B3, a partir do programa federal RenovaBio de compensação de emissões de gases de efeito estufa.

Por fim, a crise financeira de 2008, decorrente das hipotecas subprime e expressão de uma superacumulação de capitais, teve como resultado uma massa crescente de investimentos direcionando-se à terra. Harvey (2013, p. 449) explica que "o atrativo da terra como investimento [...] sempre a tornou vulnerável ao capital excedente. [E] quanto mais capital excedente existir [...] maior será a probabilidade de a terra ser absorvida na estrutura da circulação do capital".

A elevação dos preços das commodities no mercado internacional e a necessidade de áreas (agricultáveis) para a produção das flex crops, ou para fins ambientais, têm promovido esta renovada corrida mundial por terras; entretanto, a característica mais relevante e distintiva do atual fenômeno de land grabbing é justamente o interesse do capital financeiro pela agricultura, isto é, a financeirização do campo.

\section{CICLO DE REPRODUÇÃO DO CAPITAL E A RENDA DA TERRA}

A renda da terra deve ser entendida como o tributo, a taxa ou ainda "uma soma em dinheiro fixada por contrato" (MARX, 2017, v. III, p. 679) paga pelo arrendatário ao proprietário fundiário. $\mathrm{O}$ fato do proprietário monopolizar "porções definidas do globo terrestre como esferas exclusivas de sua vontade privada, com exclusão de todas as outras" (ibid., p. 676) implica que o arrendatário precisa realizar um pagamento (que é a própria renda) ao proprietário fundiário para utilizar essas terras e seus pertences, ou seja, pelo direito de "aplicar o seu capital neste campo particular da produção" (ibid., p. 679). Sendo assim, pode-se afirmar que o pressuposto da renda é justamente a propriedade de determinadas frações do planeta.

Para Marx (2017, v. III) existem quatro formas da renda: as rendas diferencial do tipo I e do tipo II, que resultam da concorrência (ou seja, ela existe apenas quando a terra entra no circuito produtivo), a absoluta, fruto da posse privada do solo e paga por toda a sociedade (existe mesmo se as terras estiverem paradas, ociosas) e a monopolista, decorrente do preço 
de monopólio de certa mercadoria produzida em terras com características singulares (OLIVEIRA, 2007).

Capitalistamente dizendo, "a renda fundiária é a expressão econômica específica da propriedade da terra” (MARX, 2017, v. III, p. 683), podendo ser vista como uma das formas metamorfoseadas ou transfiguradas do trabalho não pago, do qual se apropriam os proprietários fundiários - similar aos juros quando se trata do capital monetário - ou seja, $a$ renda é uma fração do mais-valor, ela é sempre produto do mais-trabalho (do trabalho além daquele necessário para os trabalhadores adquirirem os meios essenciais à sua subsistência).

Colocando isso em função da fórmula geral do capital, pode-se ver que o sistema de produção capitalista, mesmo sob o domínio das finanças, funda-se (e só pode fundar-se) na exploração (cada vez maior) do trabalho vivo:

$$
D \rightarrow d \rightarrow M \nearrow \searrow M p \quad \ldots \ldots \ldots \ldots \ldots . . . \quad F \quad P \rightarrow M^{\prime} \rightarrow d^{\prime} \rightarrow D^{\prime}
$$

Aqui, D refere-se ao capital portador de juros ou o capital monetário (bancos, demais instituições e investidores que possuem grande massa monetária e emprestam dinheiro no intuito de obter lucro). Em outras palavras, D é a figura do "prestamista [que] cede seu capital ao prestatário" (MARX, 2017, v. III, p. 395) d, também conhecido como capitalista funcionante que vai extrair o mais-valor ${ }^{1}\left(\Delta d=d^{\prime}-d\right)$ e retornar ao capital monetário o lucro, na forma de juros $\left(\Delta D=D^{\prime}-D\right)$ - este último, como se observa na fórmula, é uma quota-parte do mais-valor apropriada pelo prestamista ou ainda o rentista na circulação.

Dito isso, pode-se fazer a seguinte analogia: a renda futura capitalizada está para o proprietário da terra (comprador) assim como o juro/dividendo está para o investidor que adquire um título ou uma ação de uma empresa. Em outros termos,

\footnotetext{
Como a terra não é produto do trabalho, ela não pode ter um valor. A aquisição da terra 'simplesmente assegura ao comprador um direito de receber uma renda anual'. Qualquer fluxo de renda (como uma renda anual) pode ser considerado como o juro sobre algum capital fictício, imaginário. Para o comprador, a renda aparece em sua contabilidade como o juro sobre o dinheiro investido na aquisição da terra, e em princípio não é diferente de investimentos semelhantes na dívida do governo, nas ações e nas quotas das empresas, na dívida do consumidor e assim por diante. A terra se torna uma forma de capital fictício e o mercado imobiliário funciona simplesmente como um ramo particular - embora com algumas características especiais - da circulação do capital que rende juros. Nestas condições, a terra é tratada como um simples bem financeiro que é comprado e vendido segundo a renda que ele produz (HARVEY, 2013, p. 447-448, grifo nosso).
}

A terra, portanto, deixa de ser uma barreira para o capital ou aos investimentos e, como ativo financeiro, ela aparece no período atual como uma das principais formas do 
capital acumulado se valorizar. A acumulação futura se dá a partir da absorção de partes cada vez maiores do mais-valor pela captura da renda da terra (SEABRA, BICALHO, 2019), minimizando ou anulando a tendência à queda da taxa de lucro, ou seja, os efeitos decorrentes da crise financeira. Ressalta-se que a renda fundiária, o lucro industrial e os juros, categorias independentes entre si, formam o lucro no modo de produção capitalista.

No Brasil, a apreciação das terras é um negócio lucrativo mais a longo prazo, no período de 10 anos. A Figura 3 compara a valorização das terras com outros indicadores, o dólar, o Certificado de Depósito Interbancário (CDI), a Bovespa e o ouro. Observa-se que as terras se valorizaram 156\% entre agosto de 2009 e 2019, valor superior à Bovespa e ao dólar e semelhante ao CDI.

Figura 3 - Valorização das terras no Brasil, do dólar, CDI, Bovespa e ouro no prazo de 3 anos (ago./2016 a ago./2019) e 10 anos (ago./2009 a ago./2019)

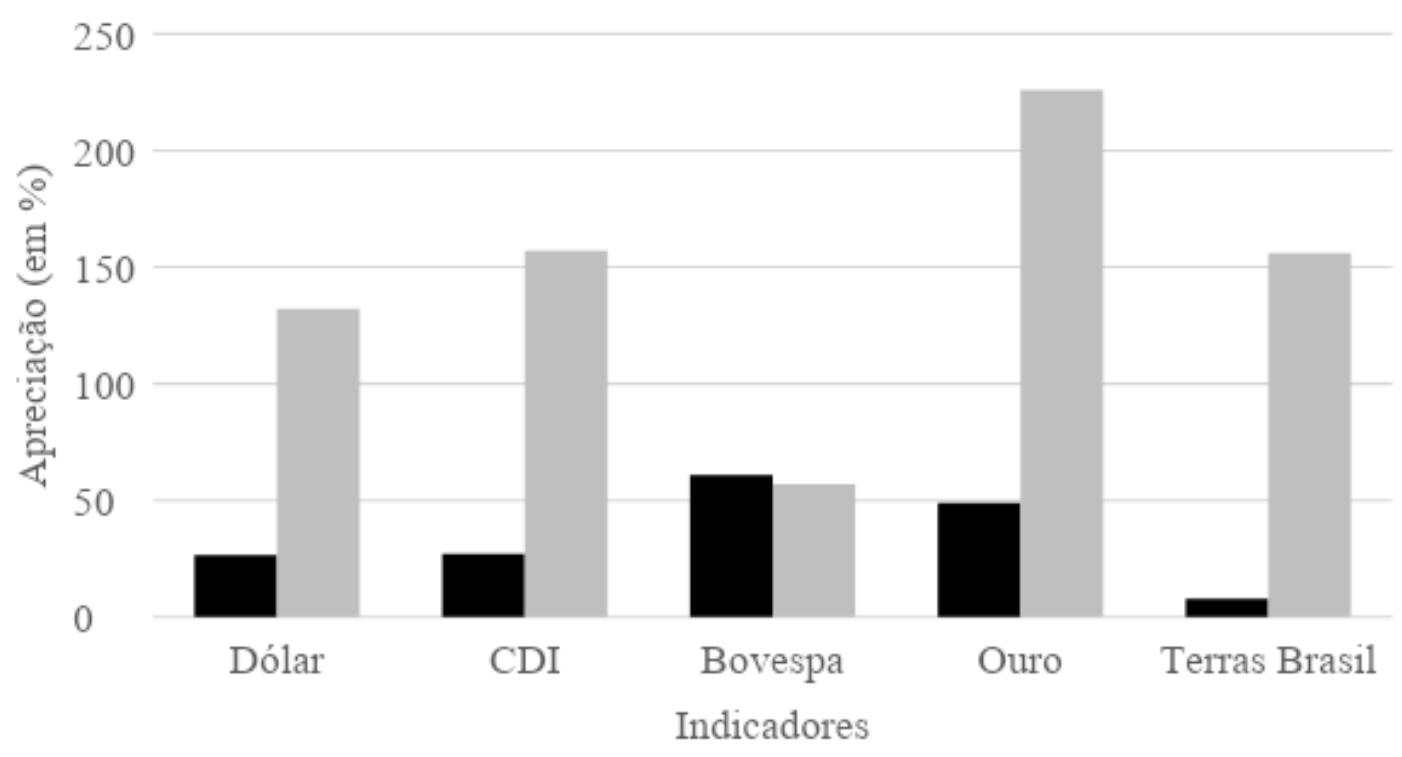

-Em 3 anos Em 10 anos

Fonte: SLC (2021)

Estes dados obtidos na publicação da empresa agrícola SLC reafirmam a interpretação da terra como um ativo financeiro, visto que ela não apenas funciona como reserva de valor e proteção contra a inflação (discurso frequente entre os investidores), mas também compete com outros investimentos, proporcionando retornos ainda mais elevados. Mesmo perdendo para as aplicações em ouro neste interstício de uma década, observa-se que a terra agrícola, diferentemente do metal, é também um ativo produtivo, funciona como um meio de produção, sendo por conta disso muitas vezes referida na mídia e nas publicações voltadas para os investidores como "black gold" ou "gold with yield" (FAIRBAIRN, 2014, p. 785). 


\section{TRANSFORMAÇÃO DA TERRA EM ATIVO FINANCEIRO}

Há uma série de mecanismos, práticas e/ou instrumentos que mostram a integração entre o capital financeiro e o controle de terras. A oferta inicial de ações (ou a realização do IPO - Initial Public Offering) é a forma possivelmente mais nítida da financeirização da agricultura. A listagem das empresas na Bolsa de Valores facilita a entrada do capital financeiro no campo, permitindo que investidores institucionais - como, fundos de pensão, fundos mútuos, firmas de private equity, fundos hedge, fundos soberanos, seguradoras, bancos, fundações universitárias, estrutura de fundos de fundos, indivíduos de alta renda passem a controlar (in) diretamente vastas extensões de terra. A compra de ações garante a estes "novos donos" de terras (mesmo que sua participação seja minoritária), lucros e renda advindos da produção agrícola e da especulação com este ativo.

A SLC Agrícola, a maior produtora de grãos e fibras do país, abriu seu capital na Bolsa em 2007. Hoje, os principais acionistas da empresa são: a SLC Participações S. A. (ou Grupo SLC) (52,27\%), empresa de capital nacional pertencente à família Logemann (que faz parte da burguesia nacional) e a Odey Asset Management Llc (9,01\%), uma companhia de investimentos inglesa que gerencia ativos para investidores institucionais, bancos privados e investidores individuais. Desde 2015, a SLC adotou uma estratégia de negócio denominada de “asset light", i.e., de desinvestimentos como meta de gestão. Na safra de 2020/21, a maior parte da área plantada pela SLC Agrícola (52\%) era oriunda de arrendamentos e joint-ventures, como mostra a Figura 4. Entretanto, mesmo com um elevado portfólio de terras não-próprias, os preços das ações da empresa tiveram um aumento expressivo a partir da safra de 2018/2019. Em junho de 2021, estes valores dispararam por conta do acordo de associação entre a SLC e outra empresa agrícola, a Terra Santa, que também tinha ações listadas na Bolsa desde 2006. Ressalta-se que as ações da Terra Santa foram incorporadas à SLC, mas isto excluiu terras e benfeitorias. Ou seja, o aumento de aproximadamente 145 mil hectares de plantio para operação, alavancou ainda mais o preço das ações da SLC, atingindo o seu valor máximo em meados de 2021, fazendo com que a terra alcançasse a forma capitalista mais desenvolvida de propriedade, a de um ativo financeiro.

Os diversos investidores institucionais também alocam seu capital "para além da porteira", isto é, em empresas a montante e a jusante da agricultura. Todo o circuito produtivo agrícola aparece como alternativa para absorver os excedentes de capital. Em 2021, em meio à gravíssima crise sanitária (que soma hoje, em novembro de 2021, mais de 610 mil mortes no país), houve um forte movimento de companhias do agronegócio realizando suas ofertas públicas iniciais de ações, cabendo citar: Agrogalaxy Participações S.A. (código de negociação, AGXY3), Boa Safra Sementes S.A. (SOJA3), Humberg Agribrasil Com. e Export. de Grãos S.A. (GRAO3), Raizen S.A. (RAIZEN), Terra Santa Propriedades Agrícolas S.A. (LAND3), Três Tentos Agroindustrial S/A (TTEN3) e Vittia Fertilizantes e Biológicos S.A (VITTIA). 
Figura 4 - Preços das ações e percentual de área própria, arrendada e de joint-ventures da SLC Agrícola, 2000-2021

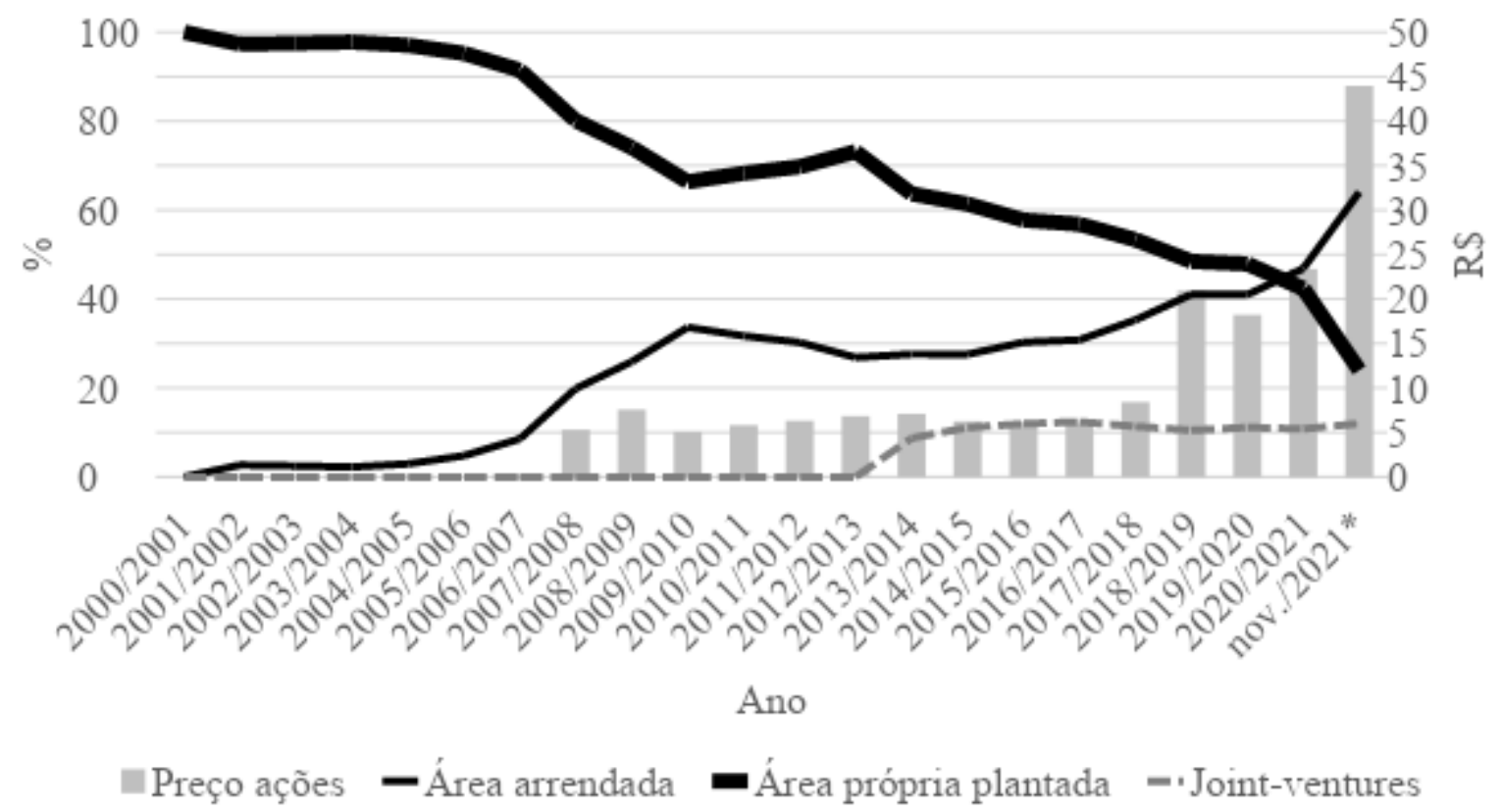

Fonte: SLC Agrícola (2021); B3

O crescimento de instrumentos do mercado de capital para o financiamento da agricultura e pecuária ampliou, da mesma forma, a participação de agentes para além do universo rural no controle de terras. Novos títulos para o financiamento do agronegócio vêm sendo criados desde 1994, como mostra a Tabela 1. Estes títulos também abrem um enorme precedente para uma maior especulação sobre a propriedade da terra, por exemplo, uma das principais inovações trazidas pela Lei do Agro (ou Lei 13.986) que criou a Cédula Imobiliária Rural (CIR) em 2020, foi a possibilidade do proprietário de imóvel rural submeter sua propriedade ou fração dela como garantia do crédito agrícola. Ou seja, cria-se um mercado de títulos de (frações de) terras, descolado dos ativos reais. Esta lei prevê ainda que, em caso de vencimento da CIR e não liquidado o crédito, o credor transfira, automaticamente, a propriedade rural para o seu nome no cartório de registro de imóveis.

Tabela 1 - Evolução dos títulos do agronegócio

\begin{tabular}{c|l|l}
\hline Ano & \multicolumn{1}{|c|}{ Título } & \multicolumn{1}{c}{ Descrição } \\
\hline \multirow{2}{*}{1994} & $\begin{array}{l}\text { Cédula de } \\
\text { Produto Rural } \\
\text { (CPR) Física }\end{array}$ & $\begin{array}{l}\text { Criada pela Lei 8.929. A CPR é emitida pelo produtor e } \\
\text { suas associações, inclusive cooperativas de produção, para a } \\
\text { venda antecipada da safra com o objetivo de levantar } \\
\text { recursos para financiar suas atividades. O produtor assume } \\
\text { o compromisso de entregar o produto físico ao comprador. }\end{array}$ \\
\hline 2001 & $\begin{array}{l}\text { Cédula de } \\
\text { Produto Rural }\end{array}$ & $\begin{array}{l}\text { Lei 10.200. A CPR-F é um tipo de CPR com liquidação } \\
\text { financeira, ou seja, pagamento em dinheiro. Emitida pelo }\end{array}$ \\
\hline
\end{tabular}




\begin{tabular}{|c|c|c|}
\hline & $\begin{array}{l}(\mathrm{CPR}) \\
\text { Financeira }\end{array}$ & $\begin{array}{l}\text { produtor para levantar recursos financeiros no mercado, } \\
\text { mas não assume compromisso de entrega do produto físico. }\end{array}$ \\
\hline 2004 & $\begin{array}{l}\text { Certificado de } \\
\text { Recebíveis do } \\
\text { Agronegócio } \\
\text { (CRA) }\end{array}$ & $\begin{array}{l}\text { Lei 11.076 (Lei 9.514/1997 criou os Certificados de } \\
\text { Recebíveis Imobiliários - CRIs que se assemelham aos } \\
\text { CRAs). O CRA é um título de crédito nominativo, } \\
\text { escritural, de livre negociação, representativo de promessa } \\
\text { de pagamento em dinheiro e constitui título executivo } \\
\text { extrajudicial. Emitido exclusivamente pelas Companhias } \\
\text { Securitizadoras de Direitos Creditórios do Agronegócio, } \\
\text { isto é, instituições não financeiras, constituídas sob a forma } \\
\text { de sociedade por ações, e que têm por finalidade a aquisição } \\
\text { e securitização desses direitos, emissão e colocação de } \\
\text { CRAs no mercado financeiro e de capitais. }\end{array}$ \\
\hline 2004 & $\begin{array}{l}\text { Letra de Crédito } \\
\text { do Agronegócio } \\
\text { (LCA) }\end{array}$ & $\begin{array}{l}\text { Lei 11.076. A LCA é um título nominativo, de livre } \\
\text { negociação, representativo de promessa de pagamento em } \\
\text { dinheiro. Emitida exclusivamente por instituições } \\
\text { financeiras públicas ou privadas. Assim, todas as } \\
\text { instituições financeiras que compõem o Sistema Financeiro } \\
\text { Nacional (SFN) e que são reguladas pelo Banco Central do } \\
\text { Brasil (BCB), inclusive as cooperativas de crédito, podem } \\
\text { emitir as LCAs. }\end{array}$ \\
\hline 2004 & $\begin{array}{l}\text { Certificado de } \\
\text { Depósito } \\
\text { Agropecuário } \\
\text { (CDA) e } \\
\text { Warrant } \\
\text { Agropecuário } \\
\text { (WA) }\end{array}$ & $\begin{array}{l}\text { Lei 11.076. O CDA é um título de crédito que representa } \\
\text { promessa de entrega de produtos agropecuários (incluindo, } \\
\text { seus derivados, subprodutos e resíduos de valor econômico) } \\
\text { depositados em armazéns certificados pelo governo ou que } \\
\text { atenda aos requisitos mínimos estabelecidos pelo Ministério } \\
\text { da Agricultura. O WA, por sua vez, é um título de crédito } \\
\text { representativo de promessa de pagamento em dinheiro, } \\
\text { conferindo direito de penhor sobre a mercadoria descrita no } \\
\text { CDA correspondente. Esses títulos são emitidos pelos } \\
\text { depositários (depósitos de armazenamento). }\end{array}$ \\
\hline 2004 & $\begin{array}{l}\text { Certificado de } \\
\text { Direitos } \\
\text { Creditórios do } \\
\text { Agronegócio } \\
\text { (CDCA) }\end{array}$ & $\begin{array}{l}\text { Lei 11.076. O CDCA é um título de crédito nominativo, } \\
\text { com livre negociação, representativo de pagamento em } \\
\text { dinheiro e constitui título executivo extrajudicial. Esses } \\
\text { títulos são emitidos exclusivamente por cooperativas de } \\
\text { produtores rurais e outras pessoas jurídicas que exerçam } \\
\text { atividades de comercialização, beneficiamento ou } \\
\text { industrialização de produtos e insumos agropecuários ou de } \\
\text { máquinas e implementos agrícolas. }\end{array}$ \\
\hline
\end{tabular}




\begin{tabular}{c|l|l}
\hline \multirow{2}{*}{$2007-2008$} & $\begin{array}{l}\text { Os GBs são títulos de dívida para captação de recursos para } \\
\text { investimentos em projetos de sustentabilidade e de } \\
\text { mitigação das mudanças climáticas. As primeiras emissões } \\
\text { ou green bonds } \\
\text { (GB) }\end{array}$ & $\begin{array}{l}\text { de título verde foram realizadas pelo Banco Europeu de } \\
\text { Investimento e pelo Banco Mundial. No Brasil, os green } \\
\text { bonds podem ser emitidos por companhias, instituições } \\
\text { financeiras, governos, corporações públicas e privadas, e } \\
\text { outros. }\end{array}$ \\
\hline \multirow{5}{*}{2020} & $\begin{array}{l}\text { Green bonds } \\
\text { para o } \\
\text { agronegócio }\end{array}$ & $\begin{array}{l}\text { Primeira emissão de título verde por produtores rurais e } \\
\text { certificada pela Climate Bond Iniciative (CBI) no mundo. } \\
\text { Foi uma operação estruturada pelo Grupo Ecoagro em favor } \\
\text { da Rizoma Agro, ambas empresas brasileiras. }\end{array}$ \\
\hline Cédula & $\begin{array}{l}\text { Lei 13.986. A CIR é um título de crédito nominativo, } \\
\text { Imobiliária } \\
\text { Rural (CIR) }\end{array}$ & $\begin{array}{l}\text { promesferível e de livre negociação, representativa de de pagamento em dinheiro, decorrente de } \\
\text { operação de crédito de qualquer modalidade. Emitida pelo } \\
\text { proprietário de imóvel rural, pessoa natural ou jurídica, que } \\
\text { houver constituído patrimônio rural em afetação. }\end{array}$ \\
\hline
\end{tabular}

Fonte: Elaborado por

De acordo com os dados coletados na B3, entre 2014 e novembro de 2021, o volume negociado de LCA no país aumentou em 61,3\%, alcançando o valor de R\$ 144,1 bilhões no final do período - mesmo ocorrendo uma queda acentuada em 2016. Já o volume financeiro depositado com o CRA cresceu em 524\% entre 2014 e 2020, atingindo R \$ 10,8 bilhões. No caso do CDCA, o volume negociado em nov./2021 foi de R $\$ 14,3$ bilhões, um aumento de $1.416,1 \%$ em relação a 2014 .

Vale destacar que, em maio de 2020, foi lançado o Finapop (Financiamento Popular), um fundo gerido por uma corretora de investimentos em parceria com cooperativas do Movimento dos Trabalhadores Rurais Sem Terra (MST). O objetivo do fundo é financiar projetos de cooperativas e associações que, normalmente, têm dificuldades de acesso ao crédito por conta de taxas altas e excesso de burocracia. No seu lançamento, o fundo arrecadou R\$ 1 milhão a partir de uma oferta restrita (apenas para investidores qualificados) para financiar uma indústria de beneficiamento de produtos agrícolas no Rio Grande do Sul. Recentemente, o Finapop anunciou outra operação, desta vez, uma oferta pública no mercado de capitais (aberta a qualquer tipo de investidor), visando levantar o montante de $\mathrm{R} \$ 17,5$ milhões via emissão de CRAs para aprimorar a produção de sete cooperativas de agricultura familiar localizadas no centro-sul do país (FURTADO, 2021).

A financeirização da terra (isto é, a transformação da terra em capital fictício) também acontece a partir dos fundos imobiliários, tipo de fundo de investimento que detém ou administra propriedades e obtém retorno - além da variação das cotas do próprio fundo - 
através da exploração da locação, do arrendamento, da venda do imóvel ou demais atividades relacionadas. Os fundos de investimento imobiliários (FIIs ou em inglês REITs - real state investment trust) foram criados nos anos 1960 nos Estados Unidos, tornaram-se mais conhecidos a partir de 1997 e, tradicionalmente, focavam no meio urbano.

Alguns anos atrás, começaram a surgir os fundos imobiliários agrícolas (FIIS agrícolas), por conta do interesse de investidores nas propriedades rurais e, mais recentemente, estes fundos passaram a ser negociados na Bolsa. Uma das primeiras companhias a formar um FII agrícola com oferta pública inicial foi a estadunidense Gladstone Land Corporation, que tem ações negociadas publicamente na Nasdaq, sob o símbolo "LAND".

No Brasil, os fundos de investimento imobiliário foram criados em 1993 e, atualmente, são regulamentados e fiscalizados pela Comissão de Valores Mobiliários (CVM). Somente no final de 2019 é que foi lançado no país o primeiro fundo de investimento imobiliário voltado para o agronegócio, o Quasar Agro FII (código na B3, QAGR11). O fundo, administrado pela instituição financeira BTG Pactual S.A., faz investimentos em ativos de infraestrutura e armazenagens. Apesar do Quasar Agro FII não investir diretamente em terras para a produção agrícola ou especulação, o controle de infraestruturas e da logística pode, em determinadas situações, implicar na transferência/apropriação da renda fundiária pelo fundo.

Mais recentemente, no final de 2020, foi listado na B3 o Riza Terrax (código RZTR11), primeiro FII que tem por objetivo investir exclusivamente em terras agrícolas no Brasil. O fundo, administrado pelo Plural S.A. Banco Múltiplo (Banco Genial) e com gestão da Riza Asset, já fez duas ofertas públicas para emissão de cotas nos valores de R $\$ 750$ e R\$ 500 milhões aproximadamente. O fundo faz 3 tipos de operações: 1) Sale \& LeaseBack aquisição de imóvel rural produtivo e arrendamento de longo prazo com o vendedor, concedendo uma opção de recompra após um prazo pré-estabelecido; 2) Buy to Lease aquisição de um imóvel rural e arrendamento a um terceiro, concedendo a este uma opção de compra do imóvel após um prazo pré-estabelecido; e 3) Land Equity - aquisição de imóvel rural e arrendamento a um terceiro, todavia não é concedida a opção de compra ao parceiro. $\mathrm{O}$ fundo tem mais de 52 mil hectares de terras distribuídas no Centro-Oeste e Nordeste, como mostra a Tabela 2 .

Tabela 2 - Carteira do fundo Riza Terrax ${ }^{2}$

\begin{tabular}{l|r|l|r|l|c}
\hline Localização & $\begin{array}{c}\text { Área total } \\
\text { (em } \\
\text { hectares) }\end{array}$ & $\begin{array}{c}\text { Tese de } \\
\text { investimento }\end{array}$ & $\begin{array}{c}\text { Valor } \\
\text { total (em } \\
\text { R\$ MM) }\end{array}$ & Arrendatário & $\begin{array}{c}\text { Prazo de } \\
\text { arrendamento } \\
\text { (em anos) }\end{array}$ \\
\hline $\begin{array}{l}\text { Bom Jesus }- \\
\text { PI }\end{array}$ & 12.272 & Buy to lease & 122,4 & Grupo Fritzen & 15 \\
\hline $\begin{array}{l}\text { Serranópolis } \\
- \text { GO }\end{array}$ & 2.304 & $\begin{array}{l}\text { Sale \& } \\
\text { Leaseback }\end{array}$ & 51,8 & $\begin{array}{l}\text { Valter Miguel } \\
\text { Giacomini }\end{array}$ & 10 \\
\hline
\end{tabular}




\begin{tabular}{|c|c|c|c|c|c|}
\hline Sorriso - MT & 2.522 & $\begin{array}{l}\text { Sale \& } \\
\text { Leaseback }\end{array}$ & 70,0 & $\begin{array}{l}\text { Agropecuária } \\
\text { Poranga }\end{array}$ & 10 \\
\hline $\begin{array}{l}\text { Nova Ubiratã } \\
-\mathrm{MT}\end{array}$ & 2.084 & $\begin{array}{l}\text { Sale \& } \\
\text { Leaseback }\end{array}$ & 58,0 & Grupo Lermen & 13 \\
\hline Sorriso - MT & 3.374 & $\begin{array}{l}\text { Sale \& } \\
\text { Leaseback }\end{array}$ & 90,5 & Grupo Fuhr & 10 \\
\hline $\begin{array}{l}\text { Buriticupu - } \\
\text { MA }\end{array}$ & 1.527 & Buy to lease & 40,1 & Scheffer & 10 \\
\hline $\begin{array}{l}\text { São José do } \\
\text { Xingu - MT }\end{array}$ & 3.354 & $\begin{array}{l}\text { Sale \& } \\
\text { Leaseback }\end{array}$ & 58,6 & Cereal Ouro & 10 \\
\hline $\begin{array}{l}\text { Rio Verde - } \\
\text { GO }\end{array}$ & 728 & $\begin{array}{l}\text { Sale \& } \\
\text { Leaseback }\end{array}$ & 5,5 & Cereal Ouro & 10 \\
\hline $\begin{array}{l}\text { Rio Verde - } \\
\text { GO }\end{array}$ & 775 & $\begin{array}{l}\text { Sale \& } \\
\text { Leaseback }\end{array}$ & 24,3 & $\begin{array}{l}\text { Grupo São } \\
\text { Tomaz }\end{array}$ & 10 \\
\hline $\begin{array}{l}\text { Formosa do } \\
\text { Rio Preto - } \\
\text { BA } \\
\end{array}$ & 7.223 & $\begin{array}{l}\text { Sale \& } \\
\text { Leaseback }\end{array}$ & 72,5 & $\begin{array}{l}\text { Sementes } \\
\text { Oilema }\end{array}$ & 10 \\
\hline $\begin{array}{l}\text { Canarana - } \\
\text { MT }\end{array}$ & 4.903 & $\begin{array}{l}\text { Sale \& } \\
\text { Leaseback }\end{array}$ & 82,4 & $\begin{array}{l}\text { Úbere } \\
\text { Agropecuária }\end{array}$ & 14 \\
\hline $\begin{array}{l}\text { Campo Verde } \\
\text { - MT }\end{array}$ & 1.632 & $\begin{array}{l}\text { Sale \& } \\
\text { Leaseback }\end{array}$ & 57,0 & Grupo Cultivo & 10 \\
\hline Balsas - MA & 1.494 & $\begin{array}{l}\text { Sale \& } \\
\text { Leaseback }\end{array}$ & 25,5 & Luis Felli & 10 \\
\hline Sorriso - MT & 8.235 & Buy to lease & 299,5 & Grupo Lermen & 13 \\
\hline
\end{tabular}

Fonte: Riza Terrax (2021)

Assim como no caso das ações, a compra de cotas de fundos imobiliários permite que o capital financeiro flua livremente para as propriedades fundiárias (sem precisar, de fato, comprá-las) e obtenha retornos (lucros e renda) sobre o seu investimento. Ressalta-se que estes tipos de investimentos garantem ao capital mobilidade e flexibilidade, pois o investidor pode a qualquer momento vender suas ações/cotas no mercado secundário.

No início de 2021, surgiu o fundo de investimento nas cadeias produtivas agroindustriais (FIAGRO). A Lei n. 14.130/2021, que criou o FIAGRO, inseriu-o dentro da Lei n. 8.668/1993 - lei que regula os Fundos de Investimento Imobiliário. Resumidamente, o FIAGRO destina-se à aplicação, de forma isolada, ou em conjunto, em: imóveis rurais; participação em sociedades que explorem atividades integrantes da cadeia produtiva agroindustrial; ativos financeiros, títulos de crédito ou valores mobiliários emitidos por pessoas físicas e jurídicas que integrem a cadeia produtiva agroindustrial; direitos creditórios do agronegócio e títulos de securitização emitidos com lastro em direitos creditórios do 
agronegócio; direitos creditórios imobiliários relativos a imóveis rurais e títulos de securitização emitidos com lastro nesses direitos creditórios; e, cotas de fundos de investimento que apliquem mais de $50 \%$ de seu patrimônio nos ativos supracitados (BRASIL, 1993, 2021).

Outro exemplo que mostra a integração entre o capital financeiro e a propriedade fundiária é o surgimento do crowdfunding de propriedades agrícolas. A plataforma FarmTogether funciona como um mercado online para investimentos em terras agrícolas nos Estados Unidos. Os investidores alocam coletivamente seu capital nas fazendas e tornam-se proprietários "fracionários". Este investimento que, em termos práticos, refere-se à compra de ações de uma empresa que detém a propriedade, garante ao investidor lucros decorrentes das operações agrícolas e ganhos de capital com a precificação da propriedade e sua posterior venda ao final do período de investimento.

Para além dos agentes das finanças, os próprios produtores rurais que, tradicionalmente, viam a terra apenas por seu valor de uso (focavam nos lucros provenientes da produção agrícola), passaram a tratar a terra também como um ativo financeiro. Desde 2007, especialmente, em países da América do Sul por conta da concentração fundiária, grandes produtores rurais passaram a criar as Imobiliárias Agrícolas - empresas dedicadas à aquisição, desenvolvimento e venda de terras - em parceria com investidores institucionais, como fundos de pensão e firmas de private equity.

Um exemplo é a empresa Cosan S/A, a maior companhia brasileira do setor sucroenergético, que em parceria com o fundo de pensão privado estadunidense TIAA (Teachers Insurance and Annuity Association of America/Associação Americana de Seguros e Anuidade de Professores) criou, em 2008, a imobiliária agrícola Radar Propriedades Agrícolas S/A. A Radar é o braço imobiliário da Cosan, ou seja, a forma pela qual esta última especula no mercado de terras (compra e vende propriedades valorizadas) (REDE, 2015). A principal estratégia da Radar é arrendar as suas terras enquanto espera a sua precificação. As terras são arrendadas para a própria Cosan, como também para produtores de grãos e fibras, como soja, milho e algodão. A Radar é o veículo para que o fundo de pensão TIAA possa atuar no mercado brasileiro de especulação de terras agrícolas. No contexto de uma crise financeira mundial, esta é uma grande oportunidade para o fundo alocar o excedente de capital nas terras em busca de sua valorização.

\section{CONSIDERAÇÕES FINAIS}

O processo de financeirização do campo tende a se aprofundar, visto que os recursos naturais aparecem como fontes de valorização, isto é, de alocação dos excedentes de capital decorrentes da crise financeira - esta, expressão de uma superacumulação. Segundo Marx, (2017, v. I, p. 679, grifo nosso) "o capital, ao incorporar os dois formadores originais da riqueza, a força de trabalho e a terra, adquire uma força expansiva que lhe permite estender 
os elementos de sua acumulação além dos limites aparentemente fixados por sua própria grandeza, limites estabelecidos pelo valor e pela massa dos meios de produção já produzidos, nos quais o capital tem sua existência" ${ }^{3}$.

Em 2021, foram lançadas no mercado três novas criptomoedas lastreadas no agronegócio brasileiro. Em julho, a Cooperativa Minasul, uma das maiores no mundo em produção de café, inaugurou a Coffee Coin, sua moeda digital. Cada Coffee Coin é gerada com a mesma equivalência a um quilo de café arábica verde (cru em grão), ou seja, ao padrão commoditizado da Bolsa de Nova York. Cooperados, investidores e o mercado em geral podem adquirir a moeda e trocá-la por produtos, incluindo o café, ou revendê-las em um mercado secundário. $\mathrm{O}$ valor do Coffee Coin é atualizado diariamente com o real valor comercial do café. No mês seguinte, em agosto, o programa de fidelidade e benefícios AgroVantagens, que funciona como uma conta digital, lançou a AgroBonus, uma criptomoeda que está vinculada ao PIB do agronegócio. As empresas cadastradas na plataforma podem receber pagamentos em Reais e em AgroBonus - apesar da moeda ainda não estar listada nas exchanges. A moeda digital agrícola mais recente é a Cultecoin, iniciativa da startup Culte. Em outubro e novembro, ocorreu a pré-venda deste token e a previsão é que, no primeiro trimestre de 2022, a moeda seja listada em exchange. Ainda antes, em abril, a Agrotoken, uma startup argentina, lançou a primeira moeda digital lastreada em grão, a Soya. O produtor entrega a produção em uma trading ou armazém e é gerado um certificado. Na plataforma da companhia, o comprovante de existência do produto é convertido em ativo digital, sendo cada uma tonelada de soja correspondente a um token Soya. É importante destacar que toda esta movimentação do mundo das finanças pode ser a mola propulsora para a criação de um mercado de criptomoedas lastreado em recursos naturais, por exemplo, de terras agricultáveis.

A financeirização dá uma impressão de uma autonomia da esfera financeira em relação à produção, como se a acumulação se resumisse em: D-D' - esta "fórmula geral e originária do capital, condensada de modo absurdo" (MARX, 2017, v. III, p. 441). Entretanto, esta "mistificação capitalista em sua forma mais descarada" (ibid., p. 442) funda-se na exploração cada vez maior do trabalho vivo. Vale lembrar que a acumulação de riqueza do agronegócio, que vem batendo recordes de receita de exportações, contrasta, no polo oposto, com a miséria da sua população. Nos últimos anos e, especialmente, com o agravamento da atual crise sanitária, grande parcela da população brasileira conviveu/está convivendo com algum grau de insegurança alimentar. São milhões de trabalhadores que passaram a ter, no seu cotidiano, a experiência da fome.

\section{NOTAS}

1 - Na esfera da produção $P$, os trabalhadores assalariados operando os meios de produção $M p$ produzem as novas mercadorias $M$, criando valores excedentes (mais-valor). Vale lembrar que a força de trabalho $F$ é uma mercadoria especial, visto que é a única mercadoria 
capaz de produzir mais valor que aquele necessário para a reprodução da própria força de trabalho.

2 - Na Tabela não estão sendo contabilizadas as terras adquiridas pelo fundo em agosto de 2021, numa transação de venda de $\mathrm{R} \$ 1,7$ bilhão em fazendas da gigante canadense Brookfield (WALENDORFF, 2021). Aponta-se que esta operação envolveu outras empresas compradoras e pessoas físicas.

3 - "Por terra, entendemos, do ponto de vista econômico, todos os objetos de trabalho fornecidos pela natureza sem a intervenção humana" (MARX, 2017, v. I, p. 684, grifo nosso).

\section{REFERÊNCIAS}

AGROTOKEN. Uma nova dimensão do agronegócio. 2021. Disponível em: <https://agrotoken.io/pt/>. Acesso em: 28 de nov. 2021.

AGROVANTAGENS. Band tv agromais. Agrovantagens, 10 jul. 2021. Disponível em:

$<$ https://www.agrovantagens.com/agromais-band $>$. Acesso em: 28 de nov. 2021.

B3. Bolsa, Balcão, Brasil. 2020. Disponível em: <http://www.b3.com.br/pt_br/>. Acesso em: 28 de nov. 2021.

BERNARDES, Júlia Adão; FREDERICO, Samuel; GRAS, Carla; HERNÁNDEZ, Valeria; MALDONADO, Valéria (Org.). Globalização do agronegócio e land grabbing: a atuação das megaempresas argentinas no Brasil. Rio de Janeiro: Lamparina, Capes, Faperj, Reagri, Mincyt, 2017. 184 p.

BICALHO, Bruna. Financeirização, land grabbing e acumulação de capital na agricultura brasileira: processo de dominação das finanças e o papel da burguesia agrária. 2020. 329 p. Tese. Instituto Brasileiro de Geografia e Estatística, Escola Nacional de Ciências Estatísticas (ENCE).

BINI, Camila. Mercado fica mais estável com etanol de milho. UNEM - União Nacional do Etanol do Milho, Mato Grosso, 5 fev. 2020. Disponível em: <http://etanoldemilho.com.br/2020/02/05/mercado-fica-mais-estavel-com-etanol-de-milho/>. Acesso em: 02 de mai. 2020.

BORRAS JR., Saturnino; KAY, Cristóbal; GÓMEZ, Sergio; WILKINSON, John. Land grabbing and global capitalist accumulation: key features in Latin America. Canadian Journal of Development Studies / Revue canadienne d'études du développement, v. 33, n. 4, p. 402-416, dez. 2012.

BRASIL. Lei no 8.668, de 25 de junho de 1993. Dispõe sobre a constituição e o regime tributário dos Fundos de Investimento Imobiliário e dos Fundos de Investimento nas Cadeias Produtivas Agroindustriais (Fiagro); e dá outras providências. (Redação dada pela Lei n ${ }^{\circ} 14.130$, de 2021). Disponível em:

$<$ http://www.planalto.gov.br/ccivil_03/leis/18668.htm>. Acesso em: 28 de nov. 2021.

. Lei no 14.130, de 29 de março de 2021. Altera a Lei $n^{\circ} 8.668$, de 25 de junho de 1993, para instituir os Fundos de Investimento nas Cadeias Produtivas Agroindustriais (Fiagro), e a Lei n ${ }^{\circ} 11.033$, de 21 de dezembro de 2004; e dá outras providências. Disponível em: <http://www.planalto.gov.br/ccivil_03/_ato2019-2022/2021/lei/L14130.htm>. Acesso em: 28 de nov. 2021.

CASTILHO, Alceu Luis; BASSI, Bruno Stankevicius; VENDRAME, Fábio. O controle de terras por estrangeiros no Brasil: panorama geopolítico, aspectos legais e macro-tendências. São Paulo: Friedrich Ebert Stiftung Brasil, 2017. 28 p.

COFFEECOIN. O coffee coin. 2021. Disponível em: <https://www.coffeecoin.com.br/>. Acesso em: 28 de nov. 2021.

COMPANHIA NACIONAL DE ABASTECIMENTO (CONAB). Acompanhamento da safra brasileira de cana-de-açúcar. Brasília: CONAB, v. 6 - Safra 2019/20, n. 4, 2020. 58 p. Disponível em: < https://www.conab.gov.br/info-agro/safras/cana> Acesso em: 2 de mai. 2020. 
CONFEDERAÇÃO DA AGRICULTURA E PECUÁRIA DO BRASIL (CNA). Guia dos títulos do agronegócio. Brasília: CNA, 2018. 28 p. Disponível em:

$<$ https://www.cnabrasil.org.br/assets/arquivos/bibliotecas/guia_titulos_agronegocio-grafica.pdf $>$. Acesso em: 28 de abr. 2020.

COTULA, Lorenzo. The international political economy of the global land rush: a critical appraisal of trends, scale, geography and drivers. The Journal of Peasant Studies, v. 34, n. 3-4, p. 649-680, 2012.

CULTECOIN. Cultecoin. 2021. Disponível em: <https://cultecoin.com/pt/>. Acesso em: 28 de nov. 2021.

EDELMAN, Marc; OYA, Carlos; BORRAS JR., Saturnino. Global land grabs: historical processes, theoretical and methodological implications and current trajectories. Third World Quarterly, v. 34, n. 9, p. 1517-1531, 2013.

EPSTEIN, Gerald. Introduction: financialization and the world economy. In: EPSTEIN, Gerald (Ed.). Financialization and the world economy. Cheltenham, UK; Northampton, USA: Edward Elgar, 2005. p. 3-16.

ESCHER, Fabiano; WILKINSON, John. A economia política do complexo Soja-Carne Brasil-China. Rev. Econ. Sociol. Rural, Brasília, v. 57, n. 4, p. 656-678, Dez. 2019. Disponível em:

$<$ http://www.scielo.br/scielo.php?script=sci_arttext\&pid=S0103-20032019000400656\&lng=en\&nrm=iso $>$. Acesso em: 13 de mar. 2020.

ESCHER, Fabiano; WILKINSON, John; PEREIRA, Paulo Rodrigues Fernandes. Causas e implicações dos investimentos chineses no agronegócio brasileiro. In: CONSELHO EMPRESARIAL BRASIL-CHINA; APEX BRASIL. China: direções globais de investimentos 2018. Brasília: ApexBrasil, 2018. 242 p. Disponível em:

$<$ http://www.apexbrasil.com.br/Content/imagens/70f2f10d-b3f9-4678-933d-f0e36d5b17ff.pdf\#page=191>. Acesso em: 13 de mar. 2020.

FAIRBAIRN, Madeleine. Foreignization, financialization and land grab regulation. Journal of Agrarian Change, v. 15, n. 4, p. 581-591, 2015.

. 'Like gold with yield': evolving intersections between farmland and finance. The Journal of Peasant Studies, v. 41, n. $\overline{5, \text { p. } 777-79,2014 .}$

FAIRHEAD, James; LEACH, Melissa; SCOONES, Ian. Green grabbing: a new appropriation of nature?. The Journal of Peasant Studies, v. 39, n. 2, p. 237-261, 2012.

FARMTOGETHER. Farmtogether. 2020. Disponível em: <https://farmtogether.com/>. Acesso em: 30 de mai. 2020.

FERNANDES, Bernardo Mançano. Estrangeirização de terras na nova conjuntura da questão agrária. In: CANUTO, Antônio; LUZ, Cássia Regina da Silva; WICHINIESKI, Isolete (Org.). Conflitos no campo Brasil 2010. Goiânia: CPT, 2011. p. $76-81$.

. Land grabbing for agro-extractivism in the second neoliberal phase in Brazil. Rev. NERA, v. 22, n. 50, p. 208-238, set.-dez. 2019.

FERNANDES, Bernardo Mançano; FREDERICO, Samuel; PEREIRA, Lorena Izá. Acumulação pela renda e disputas territoriais na fronteira agrícola brasileira. Rev. NERA, Presidente Prudente, v. 22, n. 47, p. 173-201, 2019.

FIAN; REDE SOCIAL DE JUSTIÇA E DIREITOS HUMANOS (REDE); COMISSÃO PASTORAL DA TERRA (CPT). Os custos ambientais e humanos do negócio de terras: o caso do MATOPIBA, Brasil. 2018. 96 p. Disponível em: $<$ https://fianbrasil.org.br/wp-content/uploads/2018/08/Os-Custos-Ambientais-e-Humanos-do-Nego\%CC\%81 cio-de-Terras-.p df>. Acesso em: 26 de fev. 2020.

FLEXOR, Georges; LEITE, Sérgio Pereira. Land market and land grabbing in Brazil during the commodity boom of the 2000s. Contexto Internacional, Rio de Janeiro, v. 39, n. 2, p. 393-420, Aug. 2017.

FREDERICO, Samuel; GRAS, Carla. Globalização financeira e land grabbing: constituição e translatinização das megaempresas argentinas. In: BERNARDES, Júlia Adão; FREDERICO, Samuel; GRAS, Carla; HERNÁNDEZ, Valeria; MALDONADO, Valéria (Org.). Globalização do agronegócio e land grabbing: a atuação das megaempresas argentinas no Brasil. Rio de Janeiro: Lamparina, Capes, Faperj, Reagri, Mincyt, 2017. p. 12-32.

FS BIONERGIA. Nossa empresa. São Paulo: FS Bionergia, 2020. Disponível em: $<$ http://fsbioenergia.com.br/nossa-empresa/>. Acesso em: 02 de mai. 2020. 
FUNDO MONETÁRIO INTERNACIONAL (FMI). Primary commodity prices. Washington: International Monetary Fund, 2021. Disponível em: <https://www.imf.org/en/Research/commodity-prices>. Acesso em: 28 de nov. 2021.

FURTADO, Lays. Investimentos em cooperativas da reforma agrária popular iniciam captação, nesta terça feria (27/07). MST, 27 jul. 2021. Disponível em:

$<$ https://mst.org.br/2021/07/27/investimentos-em-cooperativas-da-reforma-agraria-popular-iniciam-captacao-nesta-terca-feira 1>. Acesso em: 30 de ago. 2021.

GRAIN. Seized! The 2008 land grab for food and financial security. Barcelona: Grain, 2008. 12 p. Disponível em: $<$ https://www.grain.org/article/entries/93-seized-the-2008-landgrab-for-food-and-financial-security>. Acesso em: $28 \mathrm{de}$ abr. 2020.

HARVEY, David. O neoliberalismo: história e implicações. Tradução de Adail Sobral e Maria Stela Gonçalves. São Paulo: Edições Loyola, 2008.

. Os limites do capital. Tradução de Magda Lopes. São Paulo: Boitempo, 2013. 591 p.

INSTITUTO BRASILEIRO DE GEOGRAFIA E ESTATÍSTICA (IBGE). Pesquisa agrícola municipal. Rio de Janeiro: IBGE, 2020. Disponível em: <https://sidra.ibge.gov.br/pesquisa/pam/tabelas>. Acesso em: 28 de nov. 2021.

MARX, Karl. O capital: crítica da economia política: livro I: o processo de produção do capital/Karl Marx; Tradução de Rubens Enderle. 2 ed. São Paulo: Boitempo, 2017. 894 p.

. O capital: crítica da economia política: livro III: o processo global de produção capitalista/Karl Marx; Tradução de Rubens Enderle; edição de Friedrich Engels. 1 ed. São Paulo: Boitempo, 2017. 980 p.

MCMICHAEL, Philip. Rethinking land grab ontology. Rural Sociology v. 79, n.1, p. 34-55, 2014.

NOVACANA. Produção de etanol de milho do Brasil deve saltar 86\% em 2020/21, afirma Unem. Nova Cana, Curitiba, 21 jan. 2020. Disponível em:

$<$ https://www.novacana.com/n/etanol/mercado/producao-etanol-milho-brasil-saltar-86-2020-21-unem-210120>. Acesso em: 02 de mai. 2020.

OLIVEIRA, Ariovaldo Umbelino de. A questão da aquisição de terras por estrangeiros no Brasil: um retorno aos dossiês. Agrária, São Paulo, n. 12, p. 3-113, 2010.

. Modo capitalista de produção, agricultura e reforma agrária. São Paulo: FFLCH, 2007. 184 p.

QUASAR AGRO. O fundo: onde atuamos. São Paulo: Quasar Agro, 2020. Disponível em:

$<$ http://www.quasar.agr.br/show.aspx?idCanal=FuLpyUFodS42sDnL912Oqg==>. Acesso em: 28 de mai. 2020.

REDE BRASILEIRA DE PESQUISA EM SOBERANIA E SEGURANÇA ALIMENTAR - REDE PENSSAN. Insegurança alimentar e covid-19 no brasil. São Paulo: Rede Brasileira de Pesquisa em Soberania e Segurança Alimentar (Rede PENSSAN), 2021. 66 p. Disponível em: <https://static.poder360.com.br/2021/10/inseguranca-alimentar-no-Brasil.pdf>. Acesso em: 28 de nov. 2021.

REDE SOCIAL DE JUSTIÇA E DIREITO HUMANOS (REDE). A empresa radar s/a e a especulação com terras no Brasil. São Paulo: Editora Outras Expressões, 2015. 57 p. Disponível em: <https://www.grain.org/media/W1siZiIsIjIwMTUvMTEvMTMvMDlfMjNfMjlfNDkyX1JldmlzdGFSRURFMjAxNXBhcmF uZXRfMi5wZGYiXV0>. Acesso em: 30 de mai. 2020.

RIZA TERRAX. Relatório de gestão: julho de 2021. 2021. Disponível em:

$<$ https://www.rizaasset.com/products/riza-terrax/description>. Acesso em: 28 de nov. 2021.

RODRIGUES, Sintia Brizolla; CAMARA, Simone Bueno; ANDREATTA, Tanice; TOLEDO, Vitória Benedetti de. Analisando o "land grabbing" a partir de uma revisão sistemática. In: SEMINÁRIO INTERNACIONAL SOBRE DeSENVOLVIMENTO REGIONAL, 9, 2019, Santa Cruz do Sul. Anais...Santa Cruz do Sul: Programa de Pós Graduação em Desenvolvimento Regional - Universidade de Santa Cruz do Sul, 2019. p. 1-20. Disponível em:

$<$ https://online.unisc.br/acadnet/anais/index.php/sidr/article/view/19192/1192612408>. Acesso em: 29 de abr. 2020.

SASSEN, Saskia. Expulsões: brutalidade e complexidade na economia global. Paz e Terra: Rio de Janeiro, 2016. 341 p. 
SAUER, Sérgio; BORRAS, Saturnino. 'Land grabbing' e 'green grabbing': uma leitura da 'corrida na produção acadêmica' sobre a apropriação global de terras. Campo - Território, v. 11, n. 23, p. 6-42, jul. 2016.

SEABRA, Rogério; BICALHO, Bruna. A atualidade da renda da terra na era da financeirização. In: MARAFON, Glaucio José; CHELOTTI, Marcelo Cervo; PESSÔA, Vera Lúcia Salazar (Orgs.). Temas em geografia rural. Rio de Janeiro: EdUERJ, 2019. $468 \mathrm{p}$.

SLC AGRÍCOLA. Apresentação para investidores: o melhor da agricultura. 2021. Disponível em $<$ https://s3.amazonaws.com/mz-filemanager/a975c39b-3eca-4ad8-9330-2c0a0b8d1060/3d84959a-a41e-4a18-a08a-02310de5 3466_Apresenta\%25C3\%25A7\%25C3\%25A3o\%2520para\%2520Investidores.pdf >. Acesso em: 28 de nov. 2021.

SPADOTTO, Bruno Rezende; SAWELJEW, Yuri Martenauer; FREDERICO, Samuel; PITTA, Fábio Teixeira. Financial capital, land grabbing, and multiscale strategies of corporations specializing in the land market in the Matopiba region (Brazil). In: INTERNATIONAL CONFERENCE OF THE BRICS INITIATIVE FOR CRITICAL AGRARIAN STUDIES, 5, 2017, Moscow, Russia. Anais... Moscow: Russian Presidential Academy of National Economy and Public Administration (RANEPA), 2017. Disponível em:

$<$ https://www.iss.nl/sites/corporate/files/2017-11/BICAS\%20CP\%205-22\%20Spadotto\%20et\%20al.pdf $>$. Acesso em: $10 \mathrm{de}$ mar. 2020.

WALENDORFF, Rafael. Brookfield vende nove fazendas para riza terrax. Valor Econômico, Brasília, 17 ago. 2021. Disponível em:

$<$ https://valor.globo.com/agronegocios/noticia/2021/08/17/brookfield-vende-nove-fazendas-para-o-terrax.ghtml>. Acesso em: 30 de ago. 2021.

\section{COMO CITAR ESTE TRABALHO}

BICALHO, Bruna. A terra como ativo financeiro: mecanismos, práticas e instrumentos. Revista Tamoios, São Gonçalo, v. 18, n. 1, p. 96-116, 2022. Disponível em: https://doi.org/10.12957/tamoios.2022.63925. Acesso em: DD MMM. AAAA. 